\title{
Comparative Analysis of Learning Style Preferences Between Pre-Science and Pre-Business Students
}

\author{
Tang Howe Eng ${ }^{1^{*}} \quad$ Imelia Laura Daneil ${ }^{2}$ \\ 1.Faculty of Computer and Mathematical Sciences, Universiti Teknologi MARA Sarawak Branch, Mukah \\ Campus, 96400 Mukah, Sarawak, Malaysia \\ 2.Academy of Language Studies, Universiti Teknologi MARA Sarawak Branch, Mukah Campus, 96400 Mukah, \\ Sarawak, Malaysia
}

\begin{abstract}
Individual learning style causes a person to approach situation in different ways. As a result, it is important to investigate the learning styles of future students to improve the quality of the teaching and learning. This research used Kolb's Learning Style Inventory to compare the learning styles of pre-science and pre-business students. A survey research design was utilized and a total of 121 samples was finally analyzed. Findings revealed that prescience students were dominantly assimilator whereby pre-business students were dominantly converger. With respect to the SPM (Malaysian Certificate of Education) achievement and learning styles, ANOVA revealed that there was significant difference in SPM English between accommodator and assimilator; between accommodator and converger. On the other hand, there was significant difference in SPM Mathematics between accommodator and converger. Furthermore, pre-science students were balanced with abstract conceptualization "thinking" learning mode and concrete experience "feeling" mode and highly comfortable with active experimentation "doing" mode. Pre-business students were more comfortable with abstract conceptualization "thinking" learning mode and active experimentation "doing" mode. This research suggests that the educators should be familiar with the learning styles of their students and engage with varieties of instructional strategies to ensure the success of their students.
\end{abstract}

Keywords: comparative analysis, learning style, pre-science, pre-business, Kolb

DOI: $10.7176 / \mathrm{JEP} / 12-2-02$

Publication date: January $31^{\text {st }} 2021$

\section{Introduction}

Individual learning style causes a person to approach situation in different ways. The unique learning preferences of the students could assist their lecturers in the planning of the teaching and learning environment. Felder and Spurlin (2005) indicate that when the learning styles of students are not matched with the teaching style of their lecturer, the students feel bored and cannot pay full attention in class. Hence, the students are likely to perform poorly in their assessments, feel discouraged in their subjects and may lead to drop out from the institutions.

Learning style is one of the important elements that could vary greatly among different types of students. Students prefer to learn in multiple ways and have their own preference to receive and analyze information. Matching students' learning styles with the teaching and learning process could enable them to achieve academic success. Gappi (2013) indicates that researchers have been trying hard for decades to study the learning styles of the students with the aim to improve instruction. The more the lecturers understand on the learning differences among the students, the more efficient the teaching can take place in order to handle different needs of the students.

Year by year, pre-science and pre-business programs are introduced to help students from the science or arts stream with the necessary qualifications to further their studies at the tertiary level. Pre-science program aims to prepare the students before they join the science and technology-based diploma programs. Pre-business program aims to prepare the students before they join the social sciences and business-based diploma programs. Both programs are specifically established to cater for the students who do not qualify to go straight to diploma/matriculation and giving opportunity to the students to go for their dream ambition. An investigation on the learning styles between pre-science and pre-business students can assist the lecturers to better prepare these students for tertiary learning.

As for the entry requirement, these programs show the differences in the required qualifications. The entry requirement for pre-science students include pass SPM/SPM(V) (Malaysian Certificate of Education/ Malaysian Certificate of Education (Vocational)) or equivalent qualifications recognized by the Malaysian Government and have obtained three (3) credits including Malay Language and Mathematics, pass English Language and pass in any of the science subjects, Biology / Chemistry / Physics / Science. On the other hand, the entry requirement for pre-business students include pass SPM/SPM(V) or equivalent qualifications recognized by the Malaysian Government and have three (3) credits including Malay Language; and pass in Mathematics/Additional Mathematics and English Language. It would be very meaningful for a research to explore if the different entries yield different learning styles or different achievement of the students.

This research intends to fill in any gaps in the literature and obtain the overview on the preferred learning 
style between pre-science and pre-business students. This overview can assist the lecturers to promote teaching and learning strategies which can be the most effective to the students. Newble and Hejka (1991) argued that the impact of the educational environment on the student's learning is given minimal attention, hence more research on learning styles is needed in order to obtain a comprehensive understanding of the most commonly used learning style in the educational environments (Frances 2010).

In addition, Arredondo (2018) and Çakıroğlu (2014) urged more researches to be done on greater number of universities, courses across all areas of the business curriculum and individual student characteristics due to the many challenges. As a step to further examine the problems and needs, it is important to explore the learning needs of the students. The variable such as learning style that contributes to a student's learning ability should be addressed.

The research on the different students' learning styles could be matched to the effective teaching styles of the lecturers to further maximize students' academic achievement. Hence, this research is designed to explore the learning styles and its possible relationship on the academic achievement between pre-science and pre-business students. Specifically, this research intends to answer the following questions.

1. What are the preferred learning styles of pre-science and pre-business students?

2. What are the preferred learning modes of pre-science and pre-business students?

3. Is there any significant association between the preferred learning styles and pre-diploma programs?

4. Is there any significant difference in the academic achievement between pre-science and pre-business students in terms of different learning styles?

In the next section, the researchers explore the Kolb's experiential learning theory, the learning style concept, Kolb Learning Style Inventory and lastly, present brief review on the prior research related to learning styles.

\section{Literature Review}

This section presents on the learning style in general and the impact of learning style on the academic achievement.

\subsection{Learning Style}

Kolb (1984) introduced experiential learning theory that defined learning as a process to create knowledge through four stages of transformation of experience, naming concrete experience (feeling), reflective observation (watching), abstract conceptualization (thinking) and active experimentation (doing). Although it is likely for all four stages of learning taking place when solving problem, learners tend to select a preferred way of learning most of the time. Knowledge is expected to result from the integration of grasping and transforming experience.

Kolb defined learning styles as a cyclical process of learning experiences. The Learning Style Inventory (LSI) was developed to practise experiential learning theory and with the aim to assess an individual's preferred learning style. The LSI is a self-descriptive and self-administered instrument which consists of 12 sentences describing learning. Akella (2010) reported that the LSI matches different learning styles to complex subject matters, understand individual learning preferences and adopt different teaching methodologies to suit different learning styles of the students. McCarthy (2010) described that experiential learning theory and LSI provide detailed information on how individuals comprehend and process new information.

Kolb's model classifies learners according to accommodator, converger, assimilator and diverger. Kolb and Kolb (2005) reported that the accommodator learners are dominant in the concrete experience and active experimentation stages. They prefer to learn from hands-on experiences. The converger learners, on the other hand, are dominant in the abstract conceptualization and active experimentation stages. They tend to solve problems and make conclusions from the findings they obtained. Additionally, the assimilator learners are dominant in the abstract conceptualization and reflective observation stages. They prefer to concentrate more on ideas and abstract concepts available to them. Finally, the diverger learners are dominant in the concrete experience and reflective observation stages. They tend to view concrete situations from multiple dimensions. Face-to-face students tend to fall in the accommodating and diverging categories (Manocheri and Young 2006).

Kolb, et al. (2014) described that understanding students' learning styles can give important information for the planning of instruction which considers different student needs. In addition, Ferdig (2010) described that instruction, which plans based on the students' learning styles provides opportunities for students to follow the curriculum at an appropriate level and pace. Honigsfeld \& Dunn (2009) reported that there are claims stating that the incorporation of learning styles in designing instruction can positively influence the teaching and learning of the students.

Cezair (2003) concluded that race may have an impact on learning style. In her research, there was insufficient statistical evidence to conclude there was a significant relationship between learning style and race. However, she found out that non-white (minority) students predominantly prefer the Assimilating learning style. White students were relatively similar in their preference for the Diverging (28\%), Assimilating (28\%), Converging (24\%) and Accommodating (20\%) learning styles. 


\subsection{Impact of Learning Style on the Academic Achievement}

Tan and Laswad (2015) conducted a research relating to the impact of learning styles of undergraduate business students on their academic achievement. Students' learning styles were analyzed through Kolb Learning Styles Inventory. The findings concluded that students' learning styles are related to their academic achievement. Students with 'assimilating' style seem to perform better as compared to students with 'diverging' and 'accomodating' learning styles.

Arredondo (2018) examined the relationship between students' achievement and learning style, student characteristics and learning environment. The samples consisted of ninety undergraduate students in a public university. The findings revealed that student GPA was significantly associated with predicting student achievement and learning styles had no significant predictive relationship to student achievement. Richard

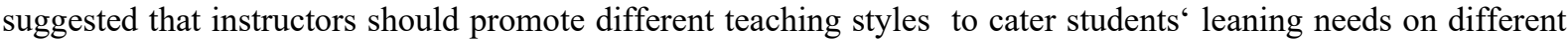
subject matter. In addition, Manocheri and Young (2006) suggested that learning styles are good predictor of student learning and this information could help schools to plan and deliver a more successful learning program..

\section{Methodology}

This research utilizes a survey research design. The population of this research comprised the entire population of pre-science and pre-business students in one branch campus of a public university in Malaysia. Every effort was taken to include all the population in this study. However, due to the missing data and samples response rate, a total sample of 121 students $(65 \%)$ was finally selected and used in the data analysis. The breakdown of prescience and pre-business students is 57 and 64 respectively.

This research utilized a questionnaire consisting of demographic profiles, SPM English, SPM Mathematics results and a 12-item Kolb Learning Styles Inventory (LSI). The LSI was designed to help individuals to determine their learning styles based on experience (Kolb 1985, Kolb and Kolb 2005). The samples self-rated their own preferences in learning situations. Each item required samples to rank items corresponding to the four learning modes, Concrete Experience (CE) with feeling characteristic; Reflective Observation (RO) with watching characteristic; Abstract Conceptualization (AC) with thinking characteristic; and Active Experimentation (AE) with doing characteristic. All the sum of the respective scores in column indicated the extent to which the sample emphasizes AC over CE and AE over RO. The LSI measures a person's relative emphasis on the four learning modes and, on two combination scores which creates the learning style types naming accommodator, assimilator, converger, and diverger. Combination scores were calculated by subtracting:

$\mathrm{AC}-\mathrm{CE}=\mathrm{Abstract}$ Conceptualization minus Concrete Experience

$\mathrm{AE}-\mathrm{RO}=$ Active Experimentation minus Reflective Observation

Column scores and combination scores were plotted on the LSI grid to determine students' learning style preference and style type.

Kolb (1995) reported that Kolb LSI produces very good internal reliability as measured by Cronbach's alpha. In addition, the combination scores show almost perfect additivity (1.0) as measured by Tukey's test. Kayes (2005) also reported that Kolb's Learning Styles Inventory (LSI) survey has demonstrated satisfactory reliability and validity. In this research, the test of reliability on Kolb LSI instrument using test-retest method resulted in high (0.9) reliability coefficients.

The questionnaire was administered to the samples in middle year 2018 and 2019. The researchers met up with the different groups after their lectures and spent about 20 minutes for the samples to complete their questionnaire. The samples were briefed that there are no right, or wrong answers and all the details were kept confidential.

The descriptive statistics was used to describe the learning styles and learning modes of the students. A chisquare test for independence was conducted to investigate whether students' preferred learning styles and prediploma programs are related. Independent samples test was conducted to investigate whether there is any significant difference in the academic achievement between pre-science and pre-business students in terms of different learning styles. The students' SPM achievement were determined by averaging their grades received in each subject. These analyses only included two subjects naming English Language and Mathematics which were the common subjects in pre-diploma programs. Analysis of Variance (ANOVA) was conducted to investigate whether there is any significant difference in the academic achievement among different learning styles of students.

\section{Findings}

The findings section is further divided into analyses on the preferred learning styles and learning modes of prescience and pre-business students; relationship between learning styles and pre-diploma programs; academic achievement by program versus learning styles and finally, ANOVA on academic achievement versus learning styles. 


\subsection{Learning Styles and Learning Modes}

Findings in Table 1 revealed that samples were observed to use assimilating and converging learning styles more than diverging and accommodating. Pre-science students were dominantly assimilator (49.1\%) as compared to converger $(35.1 \%)$. On the other hand, pre-business students were dominantly converger $(37.5 \%)$ as compared to assimilator $(16 \%)$.

Table 1. Crosstabulation on Program and Learning Styles

\begin{tabular}{|c|c|c|c|c|c|c|c|}
\hline & & \multicolumn{4}{|c|}{ Learning style } & \multirow[b]{2}{*}{ Total } \\
\hline & & & accommodator & assimilator & converger & diverger & \\
\hline \multirow[t]{6}{*}{ Program } & \multirow{3}{*}{$\begin{array}{l}\text { pre- } \\
\text { science }\end{array}$} & Count & 1 & 28 & 20 & 8 & 57 \\
\hline & & $\%$ within program & $1.8 \%$ & $49.1 \%$ & $35.1 \%$ & $14.0 \%$ & $100.0 \%$ \\
\hline & & $\%$ within style & $9.1 \%$ & $63.6 \%$ & $45.5 \%$ & $36.4 \%$ & $47.1 \%$ \\
\hline & \multirow{3}{*}{$\begin{array}{l}\text { pre- } \\
\text { business }\end{array}$} & Count & 10 & 16 & 24 & 14 & 64 \\
\hline & & $\%$ within program & $15.6 \%$ & $25.0 \%$ & $37.5 \%$ & $21.9 \%$ & $100.0 \%$ \\
\hline & & $\%$ within style & $90.9 \%$ & $36.4 \%$ & $54.5 \%$ & $63.6 \%$ & $52.9 \%$ \\
\hline \multirow{3}{*}{\multicolumn{2}{|c|}{ Total }} & Count & 11 & 44 & 44 & 22 & 121 \\
\hline & & $\%$ within program & $9.1 \%$ & $36.4 \%$ & $36.4 \%$ & $18.2 \%$ & $100.0 \%$ \\
\hline & & $\%$ within style & $100.0 \%$ & $100.0 \%$ & $100.0 \%$ & $100.0 \%$ & $100.0 \%$ \\
\hline
\end{tabular}

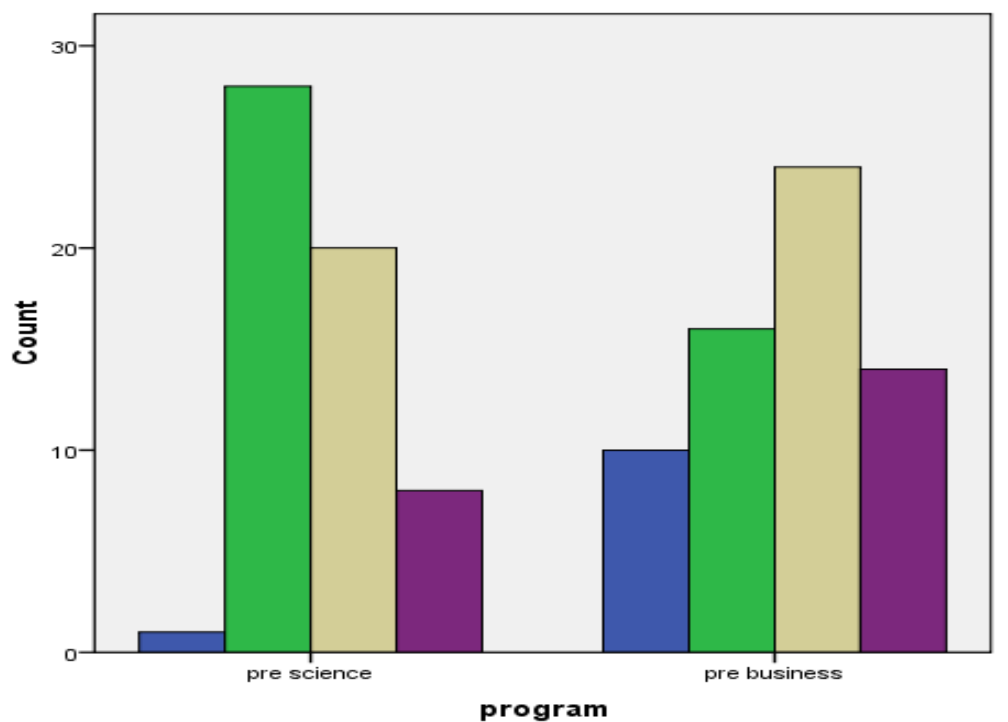

Figure 1. Clustered Bar Chart: Learning Styles by Program

The clustered bar chart (Figure 1) shows that the most preferred learning styles for pre-science students are assimilating whereby for pre-business students are converging. Comparatively, the least preferred learning styles for both pre-science and pre-business students are accommodating.

Table 2. Crosstabulation on Program and Learning Modes

\begin{tabular}{|c|c|c|c|c|c|}
\hline \multirow[t]{2}{*}{ Program } & \multirow[t]{2}{*}{ Value } & \multicolumn{4}{|c|}{ Mode } \\
\hline & & $\mathrm{AC}$ & $\mathrm{CE}$ & $\mathrm{AE}$ & $\mathrm{RO}$ \\
\hline \multirow[t]{3}{*}{ pre-science } & Frequency & 29 & 28 & 55 & 2 \\
\hline & $\%$ within program & $50.9 \%$ & $49.1 \%$ & $96.5 \%$ & $3.5 \%$ \\
\hline & $\%$ within mode & $36.7 \%$ & $66.7 \%$ & $53.9 \%$ & $10.5 \%$ \\
\hline \multirow[t]{3}{*}{ pre-business } & Frequency & 50 & 14 & 47 & 17 \\
\hline & $\%$ within program & $78.1 \%$ & $21.9 \%$ & $73.4 \%$ & $26.6 \%$ \\
\hline & $\%$ within mode & $63.3 \%$ & $33.3 \%$ & $46.1 \%$ & $89.5 \%$ \\
\hline \multicolumn{2}{|c|}{ Total Frequency } & \multicolumn{2}{|c|}{121} & \multicolumn{2}{|r|}{121} \\
\hline
\end{tabular}

As for the learning modes (Table 2), pre-science students were balanced with abstract conceptualization AC "thinking" learning mode (50.9\%) and concrete experience CE "feeling" mode (49.1\%). This proportion was 
different from pre-business students as majority of them were more comfortable with abstract conceptualization "thinking" learning mode (78.1\%).

In term of active experimentation $\mathrm{AE}$ and reflective observation RO modes (Table 2), majority of both prescience students $(96.5 \%)$ and pre-business students $(73.4 \%)$ were found highly comfortable with active experimentation "doing" mode.

\subsection{Relationship between Learning Styles and Pre-Diploma Programs}

A chi-square value of $\chi^{2}(3)=12.272, p=.007$ indicates that there is a significant association between pre-diploma programs and preferred learning styles (Table 3 ). It can be concluded that pre-science and pre-business students are not equal in their preferred learning styles, naming accommodating, assimilating, converging and diverging. The strength of association by using Cramer's V $(0.318, \mathrm{n}=121)$ shows that there is moderate significant association between learning styles and pre-diploma programs $(\mathrm{p}<0.05)$.

Table 3. Chi-Square Test on Learning Styles and Program

\begin{tabular}{|l|r|r|rr|}
\hline & \multicolumn{1}{|c|}{ Value } & \multicolumn{1}{c|}{$\mathrm{df}$} & Asymp. Sig. (2-sided) & .007 \\
\hline Pearson Chi-Square & $12.272^{\mathrm{a}}$ & 3 & .004 \\
\hline Likelihood Ratio & 13.478 & 3 & .793 \\
\hline Linear-by-Linear Association & .069 & 1 & \\
\hline N of Valid Cases & 121 & & & \\
\hline
\end{tabular}

a. 0 cells $(.0 \%)$ have expected count less than 5 . The minimum expected count is 5.18 .

As for the academic achievement, the comparison of differences for accommodating style cannot be performed as the number of respondents for pre-science only 1 student and pre-business 10 students. In this research, SPM English and SPM Mathematics are analysed as these are the common subjects in pre-diploma program.

Table 4. Group Statistics for Learning Styles in SPM English

\begin{tabular}{|c|c|c|c|c|c|c|}
\hline Learning Style & Program & $\mathrm{N}$ & Mean & Std. Deviation & $\mathrm{t}$ & Sig. (2-tailed) \\
\hline \multirow[t]{2}{*}{ Assimilator } & pre-science & 28 & 2.6071 & .42725 & \multirow[t]{2}{*}{-3.366} & \multirow[t]{2}{*}{.002} \\
\hline & pre- business & 16 & 3.0312 & .35208 & & \\
\hline \multirow[t]{2}{*}{ Converger } & pre-science & 20 & 2.8250 & .55666 & \multirow[t]{2}{*}{-1.223} & \multirow[t]{2}{*}{.228} \\
\hline & pre-business & 24 & 3.0208 & .50496 & & \\
\hline \multirow[t]{2}{*}{ Diverger } & pre-science & 8 & 2.5625 & .47716 & \multirow[t]{2}{*}{-3.296} & \multirow[t]{2}{*}{.008} \\
\hline & pre-business & 14 & 3.1786 & .30110 & & \\
\hline
\end{tabular}

Out of 44 students who were categorized as assimilator (Table 4), pre-business students $(\mathrm{n}=16)$ recorded a higher mean score of 3.03 ( $\mathrm{S} . \mathrm{D}=0.35)$ as compared to pre-science students $(\mathrm{n}=28)$ with a mean score of 2.61 (S.D $=0.43$ ) for SPM English. The standard deviations for pre-science and pre-business students do not deviate much from each other, indicating a consistent trend. With respect to the SPM (Malaysian Certificate of Education) achievement and assimilating learning styles, independent samples test revealed that there was significant difference in SPM English between pre-science and pre-business students with assimilating learning style $(\mathrm{p}<0.05)$ A total of 44 students was categorized as converger for SPM English (Table 4), among these, pre-business students $(n=24)$ recorded a higher mean score of $3.02(S . D=0.50)$ as compared to pre-science students $(n=20)$ with a mean score of $2.83(\mathrm{~S} . \mathrm{D}=0.56)$. The standard deviations for pre-science and pre-business students do not deviate much from each other, indicating a consistent trend. With respect to the SPM (Malaysian Certificate of Education) achievement and converging learning style, independent samples test revealed that there was no significant difference in SPM English between pre-science and pre-business students with converging learning style $(\mathrm{p}>0.05)$. A total of 22 students was categorized as diverger for SPM English (Table 4), among these, pre-business students $(\mathrm{n}=14)$ recorded a higher mean score of $3.18(\mathrm{~S} . \mathrm{D}=0.30)$ as compared to pre-science students $(\mathrm{n}=8)$ with a mean score of 2.56 (S.D = 0.48). With respect to the SPM (Malaysian Certificate of Education) achievement and diverging learning style, independent samples test revealed that there was a significant difference in SPM English between pre-science and pre-business students with diverging learning style $(p<0.05)$. 
Table 5. Group Statistics for Learning Styles in SPM Mathematics

\begin{tabular}{|l|l|l|l|l|l|l|}
\hline Learning Style & Program & $\mathrm{N}$ & Mean & Std. Deviation & $\mathrm{t}$ & Sig.(2-tailed) \\
\hline \multirow{2}{*}{ Assimilator } & pre-science & 18 & 2.9444 & .75516 & -1.203 & .240 \\
\cline { 2 - 8 } & pre-business & 16 & 3.1875 & .38188 & & \\
\hline \multirow{2}{*}{ Converger } & pre-science & 18 & 2.7639 & .34802 & -2.797 & .008 \\
\cline { 2 - 7 } & pre-business & 24 & 3.1458 & .49408 & & \\
\hline \multirow{2}{*}{ Diverger } & pre-science & 4 & 2.2500 & .10000 & -11.242 & .000 \\
\cline { 2 - 7 } & pre-business & 14 & 3.5000 & .41603 & & \\
\hline
\end{tabular}

Comparatively, a total of 34 students practiced assimilating learning style for SPM Mathematics (Table 5). Pre-business $(n=16)$ students recorded a higher mean score of $3.19(\mathrm{~S} . \mathrm{D}=0.38)$ as compared to pre-science students $(n=18)$ with a mean score of 2.94 (S.D = 0.76). With respect to the SPM (Malaysian Certificate of Education) achievement and assimilating learning style, independent samples test revealed that there was no significant difference in SPM Mathematics between pre-science and pre-business students with assimilating learning style $(\mathrm{p}>0.05)$.

Out of 42 students who practiced converging learning style for SPM Mathematics (Table 5), pre-business students $(n=24)$ recorded a higher mean score of $3.15(\mathrm{~S} . \mathrm{D}=0.49)$ as compared to pre-science students $(\mathrm{n}=18)$ with a mean score of $2.76(\mathrm{~S} . \mathrm{D}=0.35)$. The standard deviations for pre-science and pre-business students do not deviate much from each other, indicating a consistent trend. With respect to the SPM (Malaysian Certificate of Education) achievement and converging learning style, independent samples test revealed that there was a significant difference in SPM Mathematics between pre-science and pre-business students with converging learning style $(\mathrm{p}<0.05)$.

On the other hand, a total of 18 students practiced diverging learning style for SPM Mathematics (Table 5). Pre-business students $(n=14)$ recorded a higher mean score of $3.50(\mathrm{~S} . \mathrm{D}=0.42)$ as compared to pre-science students $(n=4)$ with a mean score of $2.25(S . D=0.10)$. With respect to the SPM achievement and diverging learning style, independent samples test revealed that there was a significant difference in SPM Mathematics between prescience and pre-business students with diverging learning style $(\mathrm{p}<0.05)$.

\subsection{ANOVA on Academic Achievement versus Learning Styles}

From the descriptive output (Table 6), for SPM English, the highest mean is seen in the accommodator group $($ Mean $=3.48 ;$ S.D. $=0.21 ; \mathrm{n}=11)$ and the lowest mean is seen in the assimilator group $($ Mean $=2.76 ;$ S.D. $=0.45$; $\mathrm{n}=44)$. The group with diverger recorded the second highest mean score with a Mean of 2.95 (S.D. $=0.47 ; \mathrm{n}=22$ ). The standard deviation which is a measure of dispersion shows that converger group has the highest S.D., followed by the diverger and then the assimilator groups.

Table 6. Descriptive Statistics on Academic Achievement and Learning Styles

\begin{tabular}{|c|c|c|c|c|c|c|c|c|c|}
\hline \multirow[t]{2}{*}{ Subject } & \multirow[t]{2}{*}{ Learning style } & \multirow[b]{2}{*}{$\mathrm{N}$} & \multirow[b]{2}{*}{ Mean } & \multirow[b]{2}{*}{$\begin{array}{c}\text { Std. } \\
\text { Deviation }\end{array}$} & \multirow[b]{2}{*}{$\begin{array}{l}\text { Std. } \\
\text { Error }\end{array}$} & \multicolumn{2}{|c|}{$\begin{array}{l}95 \% \text { Confidence } \\
\text { Interval for Mean }\end{array}$} & \multirow[b]{2}{*}{ Minimum } & \multirow[b]{2}{*}{ Maximum } \\
\hline & & & & & & $\begin{array}{l}\text { Lower } \\
\text { Bound }\end{array}$ & $\begin{array}{l}\text { Upper } \\
\text { Bound }\end{array}$ & & \\
\hline \multirow[t]{5}{*}{ SPM English } & accommodator & 11 & 3.4773 & .20780 & .06265 & 3.3377 & 3.6169 & 3.25 & 3.75 \\
\hline & assimilator & 44 & 2.7614 & .44772 & .06750 & 2.6252 & 2.8975 & 2.00 & 3.75 \\
\hline & converger & 44 & 2.9318 & .53201 & .08020 & 2.7701 & 3.0936 & 2.00 & 4.00 \\
\hline & diverger & 22 & 2.9545 & .47331 & .10091 & 2.7447 & 3.1644 & 2.00 & 3.75 \\
\hline & Total & 121 & 2.9236 & .50399 & .04582 & 2.8328 & 3.0143 & 2.00 & 4.00 \\
\hline \multirow{5}{*}{$\begin{array}{l}\text { SPM } \\
\text { Mathematics }\end{array}$} & accommodator & 11 & 3.5227 & .28405 & .08564 & 3.3319 & 3.7136 & 3.00 & 3.75 \\
\hline & assimilator & 34 & 3.0588 & .61255 & .10505 & 2.8451 & 3.2726 & 1.75 & 3.75 \\
\hline & converger & 42 & 2.9821 & .47303 & .07299 & 2.8347 & 3.1295 & 2.25 & 3.75 \\
\hline & diverger & 18 & 3.2222 & .64676 & .15244 & 2.9006 & 3.5438 & 2.25 & 3.75 \\
\hline & Total & 105 & 3.1048 & .55770 & .05443 & 2.9968 & 3.2127 & 1.75 & 3.75 \\
\hline
\end{tabular}

From the descriptive output, for SPM Mathematics, the highest mean is seen in the accommodator group $($ Mean $=3.52 ;$ S.D. $=0.28 ; \mathrm{n}=11)$ and the lowest mean is seen in the converger group $($ Mean $=2.98 ;$ S.D. $=0.47$; $\mathrm{n}=42)$. The group with diverger recorded the second highest mean score with a Mean of $3.22($ S.D. $=0.65 ; n=18)$. The standard deviation which is a measure of dispersion shows that diverger group has the highest S.D., followed by the assimilator and then the converger groups (Table 6). 
Table 7. Analysis of Variance (ANOVA) on Academic Achievement between Groups

\begin{tabular}{|c|c|c|c|c|c|c|}
\hline & & Sum of Squares & df & Mean Square & $\mathrm{F}$ & Sig. \\
\hline \multirow[t]{3}{*}{ SPM English } & Between Groups & 4.554 & 3 & 1.518 & \multirow{3}{*}{6.851} & \multirow{3}{*}{.000} \\
\hline & Within Groups & 25.926 & 117 & .222 & & \\
\hline & Total & 30.480 & 120 & & & \\
\hline \multirow[t]{3}{*}{ SPM Maths } & Between Groups & 2.873 & 3 & .958 & \multirow{3}{*}{3.282} & \multirow{3}{*}{.024} \\
\hline & Within Groups & 29.474 & 101 & .292 & & \\
\hline & Total & 32.348 & 104 & & & \\
\hline
\end{tabular}

Table 8. Multiple Comparisons Tukey HSD on Academic Achievement between Groups

\begin{tabular}{|c|c|c|c|c|c|c|c|}
\hline \multirow[b]{2}{*}{$\begin{array}{l}\text { Dependent } \\
\text { Variable }\end{array}$} & \multirow[b]{2}{*}{ (I) style } & \multirow[b]{2}{*}{ (J) style } & \multirow{2}{*}{$\begin{array}{c}\text { Mean } \\
\text { Difference (I- } \\
\mathrm{J})\end{array}$} & \multirow[b]{2}{*}{$\begin{array}{l}\text { Std. } \\
\text { Error }\end{array}$} & \multirow[b]{2}{*}{ Sig. } & \multicolumn{2}{|c|}{ 95\% Confidence Interval } \\
\hline & & & & & & $\begin{array}{l}\text { Lower } \\
\text { Bound }\end{array}$ & $\begin{array}{l}\text { Upper } \\
\text { Bound }\end{array}$ \\
\hline \multirow[t]{12}{*}{ SPM English } & \multirow[t]{3}{*}{ accommodator } & assimilator & $.71591^{*}$ & .15868 & .000 & .3023 & 1.1295 \\
\hline & & converger & $.54545^{*}$ & .15868 & .004 & .1319 & .9590 \\
\hline & & diverger & $.52273^{*}$ & .17383 & .017 & .0697 & .9758 \\
\hline & \multirow[t]{3}{*}{ assimilator } & accommodator & $-.71591^{*}$ & .15868 & .000 & -1.1295 & -.3023 \\
\hline & & converger & -.17045 & .10036 & .329 & -.4320 & .0911 \\
\hline & & diverger & -.19318 & .12292 & .399 & -.5135 & .1272 \\
\hline & \multirow[t]{3}{*}{ converger } & accommodator & $-.54545^{*}$ & .15868 & .004 & -.9590 & -.1319 \\
\hline & & assimilator & .17045 & .10036 & .329 & -.0911 & .4320 \\
\hline & & diverger & -.02273 & .12292 & .998 & -.3431 & .2976 \\
\hline & \multirow[t]{3}{*}{ diverger } & accommodator & $-.52273^{*}$ & .17383 & .017 & -.9758 & -.0697 \\
\hline & & assimilator & 19318 & .12292 & .399 & -.1272 & .5135 \\
\hline & & converger & .02273 & .12292 & .998 & -.2976 & .3431 \\
\hline \multirow[t]{12}{*}{ SPM Maths } & \multirow[t]{3}{*}{ accommodator } & assimilator & .46390 & .18738 & .070 & -.0256 & .9534 \\
\hline & & converger & $.54058^{*}$ & .18297 & .020 & .0626 & 1.0186 \\
\hline & & diverger & .30051 & .20674 & .469 & -.2396 & .8406 \\
\hline & \multirow[t]{3}{*}{ assimilator } & accommodator & -.46390 & .18738 & .070 & -.9534 & .0256 \\
\hline & & converger & .07668 & .12462 & .927 & -.2489 & .4022 \\
\hline & & diverger & -.16340 & .15747 & .728 & -.5748 & .2480 \\
\hline & \multirow[t]{3}{*}{ converger } & accommodator & $-.54058^{*}$ & .18297 & .020 & -1.0186 & -.0626 \\
\hline & & assimilator & -.07668 & .12462 & .927 & -.4022 & .2489 \\
\hline & & diverger & -.24008 & .15219 & .396 & -.6376 & .1575 \\
\hline & \multirow[t]{3}{*}{ diverger } & accommodator & -.30051 & .20674 & .469 & -.8406 & .2396 \\
\hline & & assimilator & .16340 & .15747 & .728 & -.2480 & .5748 \\
\hline & & converger & .24008 & .15219 & .396 & -.1575 & .6376 \\
\hline
\end{tabular}

*. The mean difference is significant at the 0.05 level.

With respect to the SPM (Malaysian Certificate of Education) achievement and learning styles, for SPM English, the ANOVA (Table 7) shows a significant difference in the groups $(\mathrm{F}=6.851 ; \mathrm{df}=3 ; \mathrm{p}<.05)$. Tukey HSD (Table 8) revealed that there was significant difference in SPM English between accommodator and assimilator $(\mathrm{p}<0.05)$; between accommodator and converger $(\mathrm{p}<0.05)$. On the other hand, for SPM Mathematics, the ANOVA table also shows a significant difference in the groups $(\mathrm{F}=3.282 ; \mathrm{df}=3 ; \mathrm{p}<.05)$. Tukey HSD revealed there was significant difference in SPM Mathematics between accommodator and converger $(\mathrm{p}<0.05)$. 


\section{Conclusion}

The main conclusions of this research are summarized as follow. The cross-tabulation analysis on program and learning style shows that the most preferred learning styles for pre-science students are assimilating whereby for pre-business students are converging. This finding lends support to the result by Chen et al. (2014) who reflected that assimilating was the most common learning preference, followed closely by converging. Further, this finding is also supported by Elfant (2002) and Loo (2002) who reported that undergraduate business students exhibited quite diverse learning styles and Sauceda-Castillo (2002) who reported that business students seemed to prefer converging learning style.

As for the learning modes, pre-science students were balanced with abstract conceptualization and concrete experience modes. However, majority of pre-business students were more comfortable with abstract conceptualization mode. Most pre-business students that engaged with abstract conceptualization "thinking" learning mode scored better result. This finding is parallel with Çakıroğlu (2014) who revealed that students who learn by experience and doing were related with higher learning scores. Surprisingly, majority of both pre-science students $(96.5 \%)$ and pre-business students $(73.4 \%)$ were found highly comfortable with active experimentation mode. Saudagaran (2001) stressed the importance of knowing the students learning styles in teaching and learning as students who perceived instruction was taught in the way they preferred to learn earned higher grades than students who did not.

Chi-square test concluded that pre-science and pre-business students are not equal in their preferred learning styles. This finding is found contradict with Cezair (2003) who reported that there was no significant relationship between learning style and program of research by using Kolb's Learning Style Theory. With respect to the SPM (Malaysian Certificate of Education) English achievement, firstly, independent samples test revealed that there was significant difference in SPM English between pre-science and pre-business students with assimilating learning style $(\mathrm{p}<0.05)$. Secondly, there was no significant difference in SPM English between pre-science and pre-business students with converging learning style $(\mathrm{p}>0.05)$. Lastly, there was a significant difference in SPM English between pre-science and pre-business students with diverging learning style $(\mathrm{p}<0.05)$.

On the other hand, with respect to the SPM Mathematics achievement, independent samples test revealed that there was no significant difference in SPM Mathematics between pre-science and pre-business students with assimilator learning style ( $p>0.05)$. Secondly, there was a significant difference in SPM Mathematics between prescience and pre-business students with converging learning style $(p<0.05)$. Lastly, there was a significant difference in SPM Mathematics between pre-science and pre-business students with diverging learning style $(\mathrm{p}<0.05)$. These findings are supported by Tan \& Laswad (2015) and Cheng \& Chau (2016) who revealed that students' learning styles were significantly related to academic achievement. Brunton (2015), however, suggested that student learning style had no significant effect on achievement.

With respect to the SPM achievement and learning styles, for SPM English, the ANOVA table shows a significant difference in the groups $(\mathrm{F}=6.851 ; \mathrm{df}=3 ; \mathrm{p}<.05)$. Tukey HSD revealed that there was significant difference in SPM English between accommodating and assimilating $(\mathrm{p}<0.05)$; between accommodating and converging $(\mathrm{p}<0.05)$. On the other hand, for SPM Mathematics, the ANOVA table also shows a significant difference in the groups $(\mathrm{F}=3.282 ; \mathrm{df}=3 ; \mathrm{p}<.05)$. Tukey HSD revealed there was significant difference in SPM Mathematics between accommodating and converging $(\mathrm{p}<0.05)$.

There is evidence in this research that accommodating type of learning style has a greater influence on the students' academic achievement as compared to other type of learning styles. The above finding regarding academic achievement and learning styles is found parallel with Çakıroğlu (2014) who revealed the significant relationships between the students' learning styles, study habits, and achievements in learning. However, this finding is contradicted with Arredondo (2018) who reveal the learning styles of the students had no statistically significant predictive relationship to their achievement.

This research suggests that students develop own learning styles through their daily learning, hence various instructional strategies which suit to different students' learning styles may be more effective to ensure the success of all students in their subject matter. It is recommended that future research to include a bigger diverse population, compare different models of learning styles on the academic achievement, study the impact of students' learning styles on diverse range of assessment methods in order to summarize the findings more conclusively.

The limitation of this research is its relatively small sample size especially when the samples are divided into 4 categories. Moreover, the samples were selected from one public university. Hence, it limits the generalizability of the findings obtained from this research and not possible to generalize the findings across other populations.

\section{References}

Akella, D. (2010), “'Learning Together: Kolb's Experiential Theory and Its Application”, Journal of Management \& Organization 16(1), 100-112.

Arredondo, R. J. (2018), “Multiple Regression Analysis of Student's Learning Style, Student's Characteristics and Learning Environment to Predict Student's Performance in an Introductory Accounting Course", ProQuest 
LLC., Ann Arbor, MI.

Brunton, B. (2015), "Learning Styles and Student Performance in Introductory Economics", Journal of Education for Business 90(2), 89-95.

Çakıroğlu, Ü. (2014), “Analyzing the Effect of Learning Styles and Study Habits of Distance Learners on Learning Performances: A Case of an Introductory Programming Course", International Review of Research in Open \& Distance Learning 15(4), 161-184.

Cezair, J. A. (2003), “An Exploratory Study of the Learning Styles of Undergraduate Students and the Relationship between Learning Style, Gender, Race and Student Course Achievement in Selected Accounting Courses", ProQuest Information and Learning Company, Ann Arbor, Ml.

Chen, C. C., Jones, K. T., \& Moreland, K. (2014), "Differences in Learning Styles”, CPA Journal 84(8), 46-51.

Cheng, G., \& Chau, J. (2016), "Exploring the Relationships between Learning Styles, Online Participation, Learning Achievement and Course Satisfaction: An Empirical Study of a Blended Learning Course", British Journal of Educational Technology 47(2), 257-278. doi:10.1111/bjet.12243

Clark, S., \& Latshaw, C. (2012), "Effects of Learning Styles/Teaching Styles and Effort on Performance in Accounting and Marketing", World Journal of Management 4(1), 67-81.

Elfant, B. A. (2002), “A Study of the Relationship between Integrative Studies Freshmen Learning Styles and Their Instructor's Learning Styles Represented by Students' Course Achievement”, Doctoral Dissertation, George Mason University, Virginia.

Felder, R., \& Spurlin, J. (2005), “Applications, Reliability and Validity of the Index of Learning Styles", Internatiional Journal of Engineering Education 21(1), 103-112.

Ferdig, R. E. (2010), "Understanding the Role and Applicability of K-12 Online Learning to Support Student Dropout Recovery Efforts", Michigan Virtual University, Lansing, MI.

Gappi, L. (2013), "Relationships between Learning Styles Preferences and Academic Performance of Students", International Journal of Educational Research and Technology 4(2), 70-76.

Honigsfeld, A., \& Dunn, R. (2009), "Learning-Style Responsive Approaches for Teaching Typically Performing and At-Risk Adolescents", The Clearing House 82(5), 220-224.

Kayes, D. (2005), "Internal Validity and Reliability of Kolb's Learning Style Inventory Version 3", Journal of Business and Psychology 20(2), 249-257. doi:10.1007/s10869-005-8262-4

Kolb, A. Y. \& Kolb, D. A. (2005), "Learning Styles and Learning Spaces: Enhancing Experiential Learning in Higher Education", Academy of Management Learning \& Education 4(2), 193-212.

Kolb, A., Kolb, D., Passarelli, A., \& Sharma, G. (2014), "On Becoming an Experiential Educator: The Educator Role Profile", Experienced Based Learning Systems, Inc. Retrieved from http://www.learningfromexperience.com/research library/onbecoming-an-experiential-educator

Kolb, D.A. (1995), "Learning Style Inventory Technical Specifications", Hay Group, Boston.

Kolb, D.A. (1985), "Learning Style Inventory and Technical Specifications", McBer and Company, Boston.

Kolb, D. A. (1984), "Experiential Learning: Experience as a Course of Learning and Development", Prentice Hall International, London.

Loo, R. (2002), “The Distribution of Learning Styles and Types for Hard and Soft Business Majors”, Educational Psychology 22(3), 349-360.

Manochehri, N., \& Young, J. (2006), "The Impact of Student Learning Styles with Webbased Learning or Instructor-Based Learning on Student Knowledge and Learner Satisfaction", Quarterly Review of Distance Education 7(3), 313-320.

McCarthy, M. (2010), "Experiential Learning Theory: From Theory to Practice", Journal of Business \& Economics Research 8(5), 131.

Newble, D. I. \& Hejka, E. J. (1991), “Approaches to Learning of Medical Students and Practicing Physicians: Some Empirical Evidence and Its Implications for Medical Education”, Educational Psychology 77(3/4), 333-342.

Sauceda-Castillo, M. (2002), "Learning Styles: A Comparative Study of Cultural Differences in African American, Anglo-American, Asian-American, and Hispanic-American Accounting Students in Texas Public Universities", Doctoral dissertation. UMI ProQuest Database, Texas A\&M University.

Saudagaran, M. S. (2001), "International Accounting- A User Perspective”, South Western College Publishing, Ohio.

Tan, L. M., \& Laswad, F. (2015), “Academic Performance in Introductory Accounting: Do Learning Styles Matter?” Accounting Education 24(5), 383-402. doi:10.1080/09639284.2015.1075315 